\title{
Clinicopathological features and treatment outcomes of primary laryngeal lymphomas in saudi population
}

\author{
Yasser Bayoumi ${ }^{1}$, Ahmed Marzouk Maklad ${ }^{2}$, Mutahir Ali Tunio ${ }^{3 *}$, Hanadi Fatani ${ }^{4}$, Reham AbdelMonem Mohamed ${ }^{5}$, Eyad Fawzi \\ AlSaeed ${ }^{6}$ and Mushabbab Al Asiri ${ }^{7}$ \\ *Correspondence: mkhairuddin@kfmc.med.sa \\ ${ }^{1}$ Associate Professor, Radiation Oncology, NCl, Cairo University, Cairo, Egypt and Consultant, Radiation Oncology, King Fahad \\ Medical City, Riyadh-59046, Saudi Arabia. \\ ${ }^{2}$ Lecturer Clinical Oncology, Sohag University, Sohag, Egypt and Assistant Consultant, Radiation Oncology, King Fahad Medical City \\ Riyadh-59046, Saudi Arabia. \\ ${ }^{3}$ Assistant Consultant, Radiation Oncology, Comprehensive Cancer Center, King Fahad Medical City, Riyadh, Saudi Arabia. \\ ${ }^{4}$ Consultant Head and Neck Pathologist, King Fahad Medical City, Riyadh-59046, Saudi Arabia. \\ ${ }^{5}$ Lecturer, Radiation Oncology, NCl, Cairo University, Cairo, Egypt and Assistant Consultant, Radiation Oncology, King Fahad Medical \\ City, Riyadh-59046, Saudi Arabia. \\ ${ }^{6}$ Consultant Radiation Oncology,King Khalid University Hospital, King Saud University Riyadh, Saudi Arabia. \\ ${ }^{7}$ Consultant Radiation Oncology, Comprehensive Cancer Center, King Fahad Medical City, Riyadh-59046, Saudi Arabia.
}

\begin{abstract}
Background: Primary laryngeal lymphomas (PLLs) are rare and account for $1 \%-3 \%$ of all laryngeal neoplasms. Our aim was to describe the symptomology, diagnosis, histological variants and treatment outcomes of PLL in Saudi population.

Materials and methods: Retrospective review of medical records of patients with laryngeal neoplasms, who were treated in our center in the period from July 2005 to December 2012, was performed. Demographic, radiologic and histopathological features and treatment outcomes were collected.

Results: Among 57 records of patients with laryngeal carcinoma, two (3.51\%) patients were diagnosed with PLLs. The frequent clinical presentation was hoarseness of voice. One (50\%) patient hadmarginal zone B-cell mucosa-associated lymphoid tissue (MALT) lymphomas and other (50\%) patient had T- Cell lymphoma (TCL). Both patients were treated with involved field radiotherapy 30-36 Gy in 15-18 fractions using RapidArc intensity modulated radiation therapy (IMRT). Median follow up was 12 months (6-14) with overall survival and disease free survival rates of $100 \%$ and $100 \%$.

Conclusion: PLLs are uncommon but with better outcomes than other sites lymphomas. Efforts are required for incorporation of immunohistochemical methodsto reach proper diagnosis and multimodality approach to improve the diagnosis and
\end{abstract} treatment outcomes.

Keywords: Primary laryngeal lymphomas, rare malignancy, clinicopathological features, treatment outcome, saudi population

\section{Introduction}

Primary laryngeal lymphomas (PLLs) represent $1-3 \%$ of all laryngeal cancers and less than $1 \%$ of all extranodal lymphomas [1]. Apart from supra-glottic region which contains follicular lymphoid tissue in lamina propria and ventricles, the remaining larynx is devoid of lymphoid tissue and PLLs are thought to develop from lymphocytes, that are acquired during the course of a chronic inflammatory process and for this reason, supra-glottis is commonly affected region in larynx [2]. PLLs are mainly non-Hodgkin lymphoma (NHL) and most PLLs are the diffuse large B-cell lymphoma (DLBCL) andthe mucosaassociated lymphoid tissue (MALT) lymphomas [3].

The most common sites for extra-nodal NHL in the head and neck are Waldeyer's ring, salivary glands and thyroid. The PLLs are rare and most are at stage IE or IIE at the time of diagnosis. Median age for occurrence of PLLs is the $7^{\text {th }}$ decade but can present in any groups $[4,5]$. The presenting symptoms are similar to squamous cell laryngeal cancers as; hoarseness of voice, foreign body sensation, dysphagia, stridor, dyspnea and cervical lymphadenopathy [6]. Immunohistochemistry is only confirmatory for diagnosing PLLs as radiological features are often similar to primary squamous cell laryngeal cancers [7]. PLLs are considered to respond better to multi-modality treatments as compared to other sites lymphomas [8].

The present study aimed to evaluate the clinical, pathological, radiological and treatment outcomes of patients with PLLs in Saudi population.

\section{Materials and methods}

After formal approval from institutional ethical committee, medical charts of 57 patients with confirmed pathologic diagnosis of laryngeal cancers were reviewed, who were treated in our hospital during period of July 2005 and December 2012 using computer data based system. Patients with PLLs were 
Bayoumi et al. Hematology and Leukemia 2013,

http://www.hoajonline.com/journals/pdf/2052-434X-1-5.pdf

doi: $10.7243 / 2052-434 \mathrm{X}-1-5$

Table 1. Patient's characteristics.

\begin{tabular}{|c|c|c|c|c|c|c|c|c|}
\hline No: & Age at presentation [years] & Gender & Presentation & Type & location & Stage & Treatment & Status at last visit \\
\hline 1 & 71 & M & $\begin{array}{l}\text { Hoarseness of voice } \\
\text { Foreign body sensation }\end{array}$ & $\begin{array}{c}\text { MALT } \\
\text { lymphoma }\end{array}$ & Transglottis & IE & $\begin{array}{c}\text { Radiation } \\
30 \text { Gy in } 15 \text { fractions }\end{array}$ & $\begin{array}{l}\text { CR } \\
\text { Alive }\end{array}$ \\
\hline
\end{tabular}

Abbreviations: $\mathrm{M}=$ male, $\mathrm{MALT}=$ Mucosa associated lymphoid tissue, $\mathrm{TCL}=\mathrm{T}$ cell lymphoma, $\mathrm{Gy}=\mathrm{Gray}, \mathrm{CR}=$ complete response.

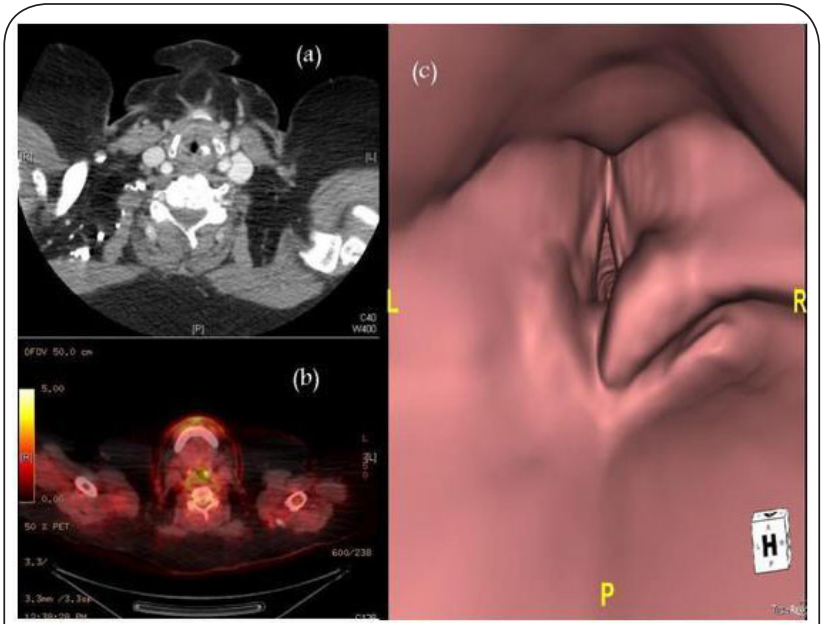

Figure 1. Case1 (a) Computed tomography showing transglottic mass with (b) SUV uptake 4.2 on CT-PET imaging and (c) virtual laryngoscopy showing right true vocal cord swelling with extension in supraglottis.

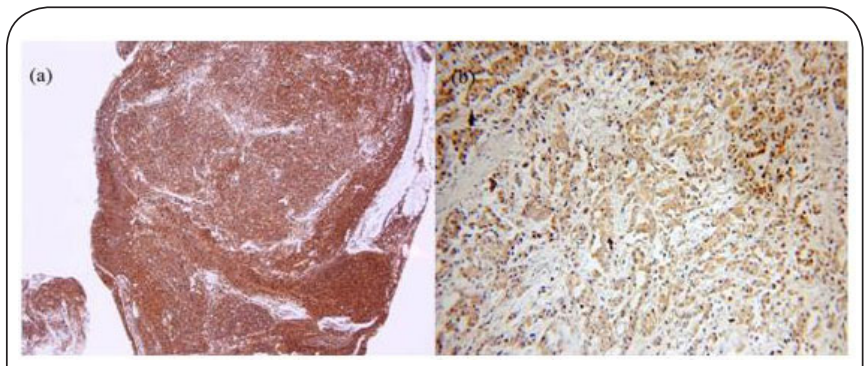

Figure 2. Immunohistochemical examination on biopsy showing positivity for (a) CD20 and (b) Bcl-2 (first case).

retrieved in following manner;

- Demographic data (age at diagnosis, gender and symptomatology).

- Histopathological characteristics: For laryngeal MALT lymphoma immunohistochemical positivity for CD20, CD45, CD15, and CD30 and negativity for BCL6, CD5, Cyclin D1, CD43 and kappa or lambda expression from core biopsy and surgery and the presence of small lymphoid cells, for T cell lymphoma/leukemia (TCL/T-ALL), appearance of diffusely infiltrating lymphocytes with immunopositivity T-cell markers (CD3 and CD45) and forHodgkin's lymphomas, presence of Reed Sternberg cells with immunopositivity for CD15 and CD30 was evaluated.Additional heavy chain Immunoglobulin (IgH) and T cell receptor (TCR) gene rearrangements, cytogenetic karyotyping and Fluorescent in Situ hybridization (FISH) were also performed for diagnosis confirmation.

- Clinical stage according to Musshoff's modification of Ann Arbor staging system [9] by findings from physical examination, hematological tests and electrolytes, computed tomography (CT) and magnetic resonance imaging (MRI) and positron emission tomography (PET) scansand bone marrow examination findings.

- Treatment modalities (surgery, chemotherapy and radiation therapy) and outcomes.

- Disease-free survival (DFS) was defined as the duration between the completion of treatment and the date of documented disease recurrence, death resulting from the cancer, and/or last follow-up visit (censored). Overall survival (OS) was defined as the duration between the completion of treatment and the date of patient death or last follow-up visit (censored).

\section{Results}

Among 57 diagnosed thyroid carcinoma patients, two (3.51\%) patients with PLLs were found. The patients' characteristics are listed in (Table 1).

\section{Case 1}

First case was 70 year-old male known hypertensive and hypothyroidism (Hashimotos' thyroiditis) with no previous history of smoking who presented to us with 12 months history of hoarseness of voice and foreign body sensation. Indirect laryngoscopy (IDL) showed mobile true vocal cords (TVC) with a huge mass in both TVC (transglottic) consistent with CT scan neck (Figure 1). The biopsy of transglottic lesion showed immunopositivity for CD20, CD3 and BCL2 + andkappa or lambda expression and immunonegativity for CD10, BCL6, CD5, Cyclin D1, and CD43. The Ki67 index was found less than 10\% (Figure 2) (showing IHC positivity for CD20 and BCL2). Baseline hematological, biochemical, hepatic, renal and lactate dehydrogenase (LDH) were found within normal limits. CT chest, abdomen, pelvis and bone marrow biopsy were found negative. Patient was staged as IE. Patient refused chemotherapy which was advised prior to radiotherapy. Patient was treated with involved field radiotherapy (IFRT) using RapidArc intensity modulated radiotherapy (IMRT) with total dose of $30 \mathrm{~Gy}$ in 15 fractions (Figure 3a). The course of treatment was tolerated well and at one year of follow up he was found alive and disease free. 


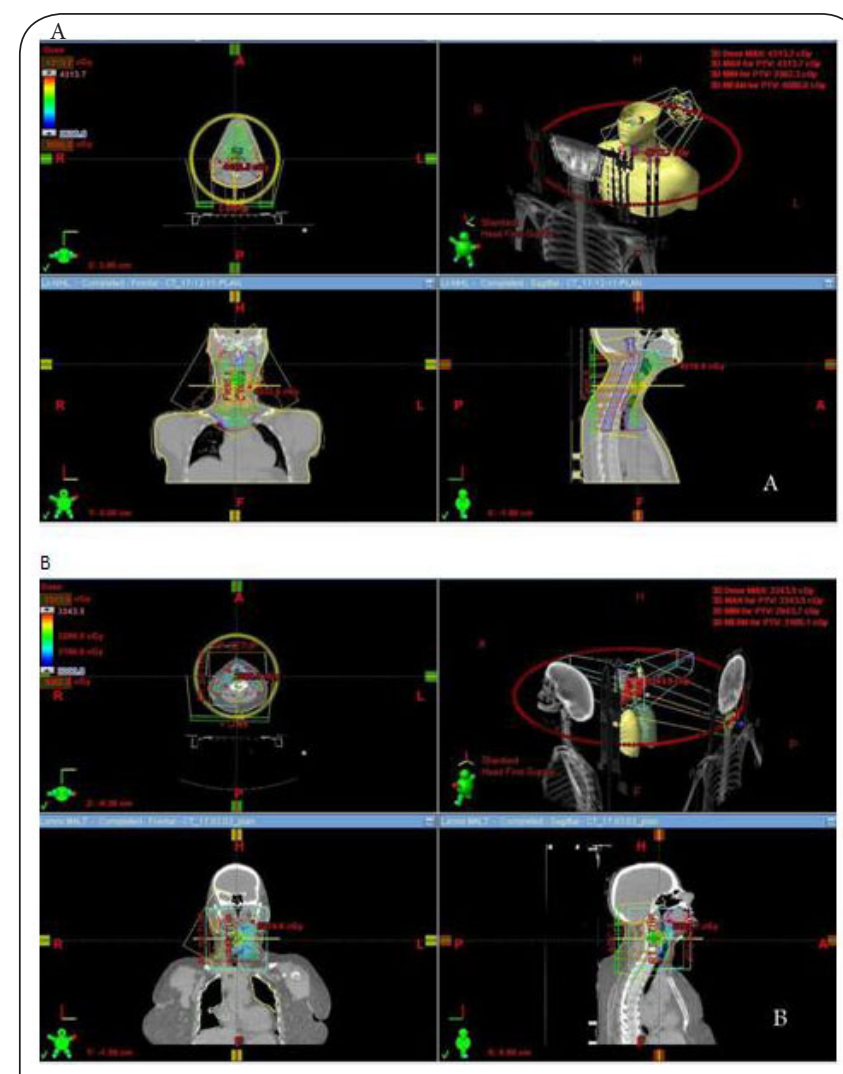

Figure 3. RapidArc IMRT field arrangements in (A) first and (B) second patient.

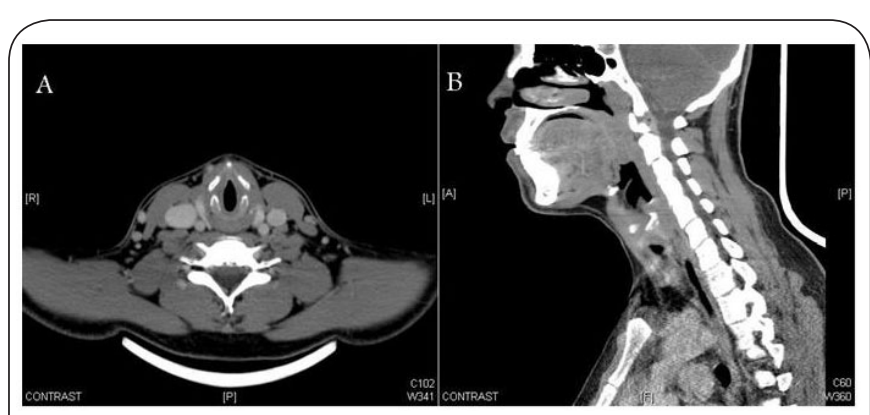

Figure 4. Computed tomography of second patient showing (A) axial and (B) sagittal views of subglottis diffuse mass.

\section{Case 2}

Second case was a 27-year old male non- smoker with no significant medical history presented to us with 6 months history of hoarseness of voice. IDL showed a submusocal thickening below level of TVCs in subglottic region consistent with CT neck findings (Figure 4). Biopsy confirmed the T cell lymphoma/T cell acute lymphoblastic leukemia. There was immunopositivity for CD99 (Figure 5), CD3, CD4, CD7, CD8 and Tdt and immunonegativity for CD5, CD10, CD20, CD34 and $\mathrm{BCL6}$. Karyotyping, IgH and PCR (to detect notch mutations) were not performed for this patient. Myeloid markers were

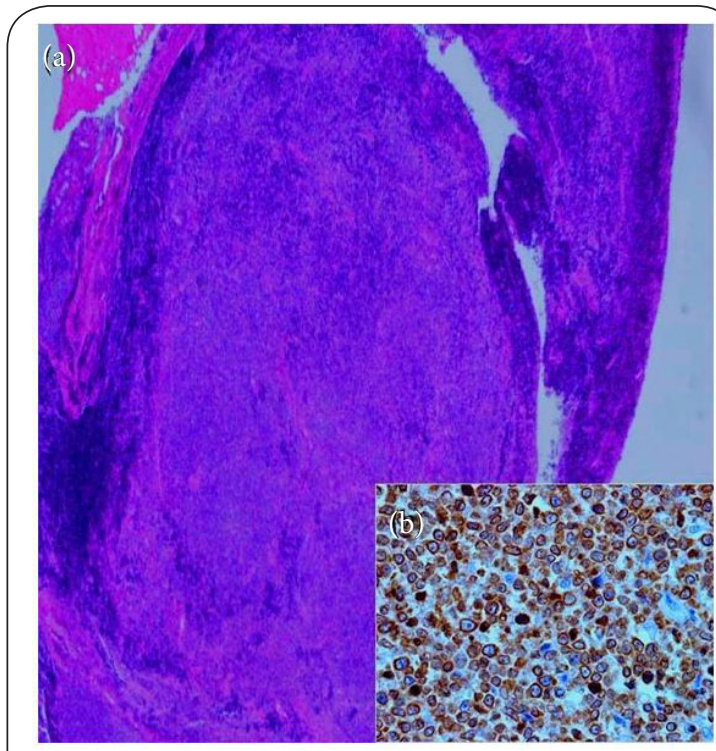

Figure 5. Case2 (a) hematoxylin and eosin showing small lymphocytes cell (low power magnification $\mathrm{x} 100$ ) and (b) immunohistochemistry showing positivity for CD99.

done to exclude a myeloid neoplasm with any aberrant $\mathrm{T}$ cell expression.Baseline LDH, hematological, biochemical, hepatic and renal functions were found normal. Remaining staging work up was negative and he was staged as IE. Patient refused chemotherapy and he was treated with IFRT using RapidArc IMRT with total dose 36 Gy in 18 fractions (Figure 3b). The treatment was tolerated well with grade 1 dysphagia. At 12 months, he was alive with complete recovery of normal and disease free.

\section{Discussion}

PLLs are rare with diverse clinicopathological features and treatment outcomes as reported in previous published data (Table 2). In our series, PLLs were seen $3.51 \%$ of all laryngeal malignancies which is much higher frequency as reported by other studies. PLLs were seen in $3^{\text {rd }}$ and $7^{\text {th }}$ decade and predominantly in males. Predominant histopathological type DLBCL was not seen in our both patients and both patients had non-supraglottic involvement of larynx with stage IE. Causative factors for PLLs are not well known, however, PLLs cases have seen in patients with Wiskott Aldrich syndrome, acquired immunodeficiency syndrome (AIDS), rheumatoid arthritis and Sjogrens syndrome $[19,30,41,42]$. Our first patient had Hashimoto's thyroiditis.

Diagnosis is challenging as radiological features are similar to other squamous cell laryngeal cancers as in our patient CT/PET imaging was non diagnostic. Incorporation of immunohistochemistry $(\mathrm{IHC})$ is only a confirmatory tool. We treated both patients with radiotherapy with excellent response rates. Due to rarity of PLLs there is no consensus 
Bayoumi et al. Hematology and Leukemia 2013,

http://www.hoajonline.com/journals/pdf/2052-434X-1-5.pdf

doi: $10.7243 / 2052-434 \mathrm{X}-1-5$

Table 2. Case reports and series of primary laryngeal lymphoma published between 1986 to 2013 .

\begin{tabular}{|c|c|c|c|c|c|c|c|c|}
\hline Authors & Age/ Gender & Symptoms & Location & Histologic type & Stage & Treatment & Follow up & Status \\
\hline Ghosh KC, et al., [10] & $60 / \mathrm{M}$ & $\begin{array}{l}\text { Hoarseness of voice } \\
\text { Stridor }\end{array}$ & Subglottis & DLBCL & IE & $\begin{array}{l}\text { Tracheostomy and RT } \\
19 \text { Gy in } 8 \text { fractions }\end{array}$ & 4 months & Alive \\
\hline Diebold J, et al., [11] & $46 / \mathrm{M}$ & NA & Supraglottis & MALT & IE & RT & NA & NA \\
\hline Hisashi K, et al., [12] & $66 / \mathrm{M}$ & Hoarseness of voice & Glottis & MALT + SCC & IE & $\begin{array}{l}\mathrm{RT}+\text { total Laryngec- } \\
\text { tomy }\end{array}$ & 46 months & Alive \\
\hline Kato S, et al., [13] & 3 cases $M$ & Hoarseness of voice & $\begin{array}{l}\text { Supraglottis (2) } \\
\text { Glottis (1) }\end{array}$ & MALT (2)TCL (1) & $\begin{array}{l}\text { IE (2) } \\
\text { IV (1) }\end{array}$ & $\begin{array}{c}\text { CT (3) } \\
\text { RT (2 cases) } \\
\text { Laryngectomy (1) }\end{array}$ & NA & NA \\
\hline Ansell SM, et al., [14] & 6 cases $M$ & Hoarseness of voice & $\begin{array}{l}\text { Supraglottis(2) } \\
\text { Glottis (3) } \\
\text { Subglottis(1) }\end{array}$ & $\begin{array}{c}\text { MALT (3)MALT } \\
\text { (3) }\end{array}$ & IE & CT (2) RT (4) & $\begin{array}{l}40-228 \\
\text { months }\end{array}$ & $\begin{array}{l}\text { Dead (5) } \\
\text { Alive (1) }\end{array}$ \\
\hline $\begin{array}{l}\text { Marianowski R, et al., } \\
\text { [15] }\end{array}$ & $88 / \mathrm{M}$ & Hoarseness of voice & Supraglottis & TCL & IE & $\begin{array}{c}\mathrm{RT}+\mathrm{CT} \\
\text { (chlorambucil) } \\
\text { Steroids }\end{array}$ & 10 months & Dead \\
\hline Fung EK, et al., [16] & $78 / \mathrm{M}$ & $\begin{array}{c}\text { Hoarseness of voice } \\
\text { Dyspnea } \\
\text { Dysphagia }\end{array}$ & Supraglottis & MALT & IE & $\begin{array}{c}\text { RT } \\
44 \text { Gy in } 22 \text { fractions }\end{array}$ & 30 months & Alive \\
\hline Zhao JD, et al., [17] & 5 cases $M$ & $\begin{array}{l}\text { Hoarseness of voice } \\
\text { and dysphagia }\end{array}$ & Supraglottis & DLBCL & $\begin{array}{l}\text { IE (3) } \\
\text { IV (2) }\end{array}$ & $\mathrm{RT}+\mathrm{CT}$ & 24 months & NA \\
\hline $\begin{array}{l}\text { Hadjileontis CG, et al., } \\
\text { [18] }\end{array}$ & $53 / \mathrm{M}$ & Hoarseness of voice & Glottis & $\mathrm{TCL}+\mathrm{SCC}$ & NA & NA & NA & NA \\
\hline Palenzuela G, et al., [19] & $15 / \mathrm{M}$ & $\begin{array}{l}\text { Hoarseness of voice } \\
\text { Dyspnea }\end{array}$ & Trans glottis & DLBCL & NA & $\mathrm{RT}+\mathrm{CT}$ & 2 months & Dead \\
\hline Kania RE, et al., [20] & $70 / \mathrm{M}$ & Hoarseness of voice & Glottis & MALT & IE & Surgical Excision & 24 months & Alive \\
\hline Roca B, et al., [21] & $82 / \mathrm{F}$ & $\begin{array}{l}\text { Hoarseness of voice } \\
\text { Dysphagia }\end{array}$ & Supraglottis & DLBCL & IE & $\mathrm{RT}$ & 12 months & Alive \\
\hline $\begin{array}{l}\text { Andratschke } M, \text { et al., } \\
\text { [22] }\end{array}$ & $58 / \mathrm{M}$ & Severe dyspnea & Subglottis & MALT & IE & $\mathrm{RT}+\mathrm{CT}$ & 12 months & Alive \\
\hline Word R, et al., [23] & $76 / \mathrm{M}$ & Hoarseness of voice & Supraglottis & DLBCL & IE & $\mathrm{CT}(\mathrm{RCHOP})$ & 36 months & Alive \\
\hline Steffen A, et al., [24] & $62 / \mathrm{M}$ & $\begin{array}{l}\text { Dry cough, stridor } \\
\text { and exertional } \\
\text { dyspnea }\end{array}$ & Subglottis & MALT & IE & CT (CHOP) & 15 months & Alive \\
\hline Tardío JC,et al., [25] & $52 / \mathrm{M}$ & $\begin{array}{l}\text { Hoarseness of voice- } \\
\text { Dyspnea }\end{array}$ & Supraglottis & $\begin{array}{l}\text { NK/T-cell lym- } \\
\text { phoma }\end{array}$ & IIE & $\mathrm{CT}$ & 6 months & Dead \\
\hline Monobe H, et al., [26] & $73 / \mathrm{M}$ & Dyspnea & Supraglottis & $\begin{array}{l}\text { NK/T-cell lym- } \\
\text { phoma }\end{array}$ & IE & $\mathrm{CT}$ & 12 months & Dead \\
\hline Markou K, et al., [4] & $\begin{array}{l}3 \text { cases } \\
67 / \mathrm{M} \\
53 / \mathrm{M} \\
32 / \mathrm{M}\end{array}$ & $\begin{array}{c}\text { Hoarseness of voice } \\
\text { Dyspnea } \\
\text { Stridor }\end{array}$ & $\begin{array}{c}\text { Glottis (2) } \\
\text { Subglottis (1) }\end{array}$ & $\begin{array}{c}\text { TCL (1) } \\
\text { MALT (1) } \\
\text { ALBL +SCC (1) }\end{array}$ & $\begin{array}{l}\text { IE (2) } \\
\text { IIE (1) }\end{array}$ & $\begin{array}{c}\text { CT (2) } \\
\text { CT +RT (1) } \\
40 \text { Gy in } 20 \text { fractions }\end{array}$ & $\begin{array}{l}\text { 26-80 } \\
\text { months }\end{array}$ & Alive \\
\hline Elmazghi A, et al., [27] & $24 / \mathrm{M}$ & $\begin{array}{l}\text { Hoarseness of voice } \\
\text { Dyspnea }\end{array}$ & Supraglottis & DLBCL & IIE & $\begin{array}{l}\mathrm{CT}(\mathrm{CHOP})+\mathrm{RT} 40 \\
\text { Gy in } 20 \text { fractions }\end{array}$ & 6 months & Alive \\
\hline Uri N, et al., [28] & $45 / \mathrm{M}$ & $\begin{array}{l}\text { Hoarseness of voice } \\
\text { Dyspnea }\end{array}$ & Supraglottis & $\begin{array}{l}\text { NK/T-cell lym- } \\
\text { phoma }\end{array}$ & IE & $\begin{array}{c}\text { RT } 40 \text { Gy in } 20 \text { frac- } \\
\text { tions }\end{array}$ & 24 months & Alive \\
\hline Naciri S, et al., [29] & $70 / \mathrm{M}$ & Severe dyspnea & Subglottis & $\begin{array}{l}\text { Mantle Cell lym- } \\
\text { phoma }\end{array}$ & IIIE & $\begin{array}{c}\text { Tracheostomy }+\mathrm{CT} \\
\text { (RCHOP) }\end{array}$ & 2 months & Dead \\
\hline Cikojevic D, et al., [7] & $77 / \mathrm{M}$ & $\begin{array}{l}\text { Dysphagia } \\
\text { Cough } \\
\text { Foreign body } \\
\text { sensation }\end{array}$ & Supraglottis & $\begin{array}{l}\text { NK/T-cell lym- } \\
\text { phoma }\end{array}$ & IIE & $\begin{array}{c}\mathrm{CT}(\mathrm{CHOP})+\mathrm{RT} \\
40 \text { Gy in } 20 \text { fractions }\end{array}$ & 12 months & Alive \\
\hline Smith MS, et al., [30] & NA & $\begin{array}{l}\text { Hoarseness of voice } \\
\text { Dyspnea }\end{array}$ & Supraglottis & TCL & IE & $\begin{array}{c}\text { RT } \\
40 \text { Gy in } 20 \text { fractions }\end{array}$ & 12 months & Dead \\
\hline Simo R, et al., [31] & NA & Hoarseness of voice & Glottis & DLBCL & IE & $\begin{array}{c}\text { RT } \\
40 \text { Gy in } 20 \text { fractions }\end{array}$ & 8 months & Dead \\
\hline de Bree R, et al., [32] & $36 / \mathrm{F}$ & $\begin{array}{l}\text { Hoarseness of voice } \\
\text { Dyspnea }\end{array}$ & Supraglottis & MALT & IE & $\begin{array}{c}\text { RT } \\
28 \text { Gy in } 14 \text { fractions }\end{array}$ & 24 months & Alive \\
\hline Cheng CJ, et al., [33] & NA & $\begin{array}{l}\text { Hoarseness of voice } \\
\text { Dyspnea }\end{array}$ & Supraglottis & DLBCL & IE & RT & 12 months & Alive \\
\hline Ohta N, et al., [34] & $76 / \mathrm{M}$ & Dysphagia & Supraglottis & DLBCL & IE & Laryngectomy + RT & 36 months & Alive \\
\hline Cavalot AL, et al., [35] & NA & Hoarseness of voice & Glottis & DLBCL & IE & $\mathrm{CT}$ (CHOP) & 16 months & Alive \\
\hline Mok JS, et al., [36] & 3 cases & $\begin{array}{l}\text { Hoarseness of voice } \\
\text { Dyspnea }\end{array}$ & $\begin{array}{l}\text { Supraglottis (2) } \\
\text { Subglottis (1) }\end{array}$ & $\begin{array}{l}\text { NK/T-cell (2) } \\
\text { TCL (1) }\end{array}$ & $\begin{array}{c}\text { IE (1) } \\
\text { IIE (2) }\end{array}$ & $\begin{array}{l}\text { CT (3) } \\
\text { RT (1) }\end{array}$ & NA & Dead \\
\hline
\end{tabular}


Bayoumi et al. Hematology and Leukemia 2013,

http://www.hoajonline.com/journals/pdf/2052-434X-1-5.pdf

doi: 10.7243/2052-434X-1-5

Continuation of Table 2.

\begin{tabular}{|c|c|c|c|c|c|c|c|c|}
\hline Authors & Age/ Gender & Symptoms & Location & Histologic type & Stage & Treatment & Follow up & Status \\
\hline Nayak JV, et al., [37] & NA & $\begin{array}{c}\text { Hoarseness of voice } \\
\text { Dyspnea }\end{array}$ & Supraglottis & DLBCL & NA & CT & 13 months & Alive \\
\hline Caletti G, et al., [38] & NA & Hoarseness of voice & Glottis & MALT & IE & $\begin{array}{c}\text { Anti-Helicobacter } \\
\text { pylori therapy }\end{array}$ & 46 months & Alive \\
\hline King $\mathrm{AD}$, et al., [39] & 3 cases & Hoarseness of voice & Trans glottis & NK/T-cell (3) & IE & $\begin{array}{l}\text { CT (3) } \\
\text { RT (1) }\end{array}$ & 11-36 months & $\begin{array}{l}\text { Dead (1) } \\
\text { Alive (2) }\end{array}$ \\
\hline Agada FO, et al., [40] & NA & $\begin{array}{c}\text { Hoarseness of voice } \\
\text { Dyspnea }\end{array}$ & Supraglottis & DLBCL & IE & CT & 6 months & Alive \\
\hline Patiar S, et al., [41] & NA & $\begin{array}{c}\text { Hoarseness of voice } \\
\text { Dyspnea }\end{array}$ & Supraglottis & DLBCL & IE & $\mathrm{CT}$ & NA & Alive \\
\hline Korst RJ, et al., [42] & NA & $\begin{array}{l}\text { Hoarseness of voice } \\
\text { Stridor }\end{array}$ & Subglottis & MALT & IIE & Laryngectomy & 4 months & Alive \\
\hline Monobe $\mathrm{H}$, et al.,[43] & $73 / \mathrm{M}$ & $\begin{array}{c}\text { Hoarseness of voice } \\
\text { Dyspnea }\end{array}$ & Supraglottis & NK/T-cell & IIE & CT & 1.5 months & Dead \\
\hline
\end{tabular}

for radiation therapy doses and fractionation and radiation doses between 19 Gy to 44 Gy have been given in past reports $[4,10,16,27,28,30,32]$. RCHOP (cyclophosphamide, doxorubicin, vincristine, prednisone and rituximab) chemotherapy alone also have shown complete regression of PLLs in many patients $[23-26,35,37,40,41,43]$. However we believe that multimodality approach (chemotherapy regimen and radiation therapy) shall be encouraged for such patients and laryngectomy or tracheostomy should only be performed in patients withstrider or coexistent squamous cell laryngeal cancers, as PLLs respond well with chemotherapy and radiotherapy. Excellent outcomes in our in both patients without prior induction chemotherapy were possibly due to early stage PLLs and use of novel radiation therapy techniques (Rapid IMRT).

In conclusion, PLLs are rare with considerable heterogeneous behavior and clinicopathologic features in our Saudi population. With improvements in IHC frequency of PLLs is rising and multimodality approach shall be considered for treating such patients.

\section{Competing interests}

The authors declare that they have no competing interests.

\section{Authors' contributions}

YB: concept of study, MAA, EFA: manuscript writing and related research data collection, HF: pathological data writing and collection, YB, MAT: statistical analysis, manuscript writing, AMM, KR: data collection, manuscript editing.

\section{Publication history}

Editor: Julie Teruya-Feldstein, Memorial Hospital for Cancer and Allied Diseases, USA.

Received: 09-May-2013 Revised: 29-May-2013

Accepted: 24-Jun-2013 Published: 26-Jun-2013

\section{References}

1. Horny HP, Ferlito A and Carbone A: Laryngeal lymphoma derived from mucosa-associated lymphoid tissue. Ann Otol Rhinol Laryngol 1996, 105:577-83. | Article | PubMed

2. Morgan K, MacLennan KA, Narula A, Bradley PJ and Morgan DA: NonHodgkin's lymphoma of the larynx (stage IE). Cancer 1989, 64:1123-7. Article | PubMed
3. Pak MW, Woo JK and Van hasselt CA: T-cell non-Hodgkin's lymphoma of the larynx and hypopharynx. Otolaryngol Head Neck Surg 1999, 121:335-6. | Article | PubMed

4. Markou K, Goudakos J, Constantinidis J, Kostopoulos I, Vital V and Nikolaou A: Primary laryngeal lymphoma: report of 3 cases and review of the literature. Head Neck 2010, 32:541-9. | Article | PubMed

5. Cohen SR, Thompson JW and Siegel SE: Non-Hodgkin's lymphoma of the larynx in children. Ann Otol Rhinol Laryngol 1987, 96:357-61. | Article | PubMed

6. Kawaida M, Fukuda H, Shiotani A, Nakagawa H, Kohno $\mathrm{N}$ and Nakamura A: Isolated non-Hodgkin's malignant lymphoma of the larynx presenting as a large pedunculated tumor. ORL J Otorhinolaryngol Relat Spec 1996, 58:171-4. | Article | PubMed

7. Cikojevic D, Gluncic I, Pesutic-Pisac V, Klancnik M and Colovic Z: Primary laryngeal NK/T-cell non-Hodgkin lymphoma: a case report. Ear Nose Throat J 2012, 91:E10-2. | PubMed

8. Roca B, Vidal-Tegedor B and Moya M: Primary non-hodgkin lymphoma of the larynx. South Med J 2005, 98:388-9. | Article I PubMed

9. Harris NL, Jaffe ES, Stein H, Banks PM, Chan JK, Cleary ML, Delsol G, De Wolf-Peeters C, Falini B, Gatter KC and et al.: A revised EuropeanAmerican classification of lymphoid neoplasms: a proposal from the International Lymphoma Study Group. Blood 1994, 84:1361-92. | Article | PubMed

10. Ghosh KC, Chatterjee DN, Mukherjee D, Mondal A and Mukherjee AL: Primary non-Hodgkin's lymphoma of larynx (a case report). J Postgrad Med 1986, 32:103-4. | Article | PubMed

11. Diebold J, Audouin J, Viry B, Ghandour C, Betti P and D'Ornano G: Primary lymphoplasmacytic lymphoma of the larynx: a rare localization of MALT-type lymphoma. Ann Otol Rhinol Laryngol 1990, 99:577-80. | PubMed

12. Hisashi K, Komune S, Inoue H, Komiyama S, Sugimoto T and Miyoshi M: Coexistence of MALT-type lymphoma and squamous cell carcinoma of the larynx. J Laryngol Otol 1994, 108:995-7. | Article I PubMed

13. Kato S, Sakura M, Takooda S, Sakurai M and Izumo T: Primary nonHodgkin's lymphoma of the larynx. J Laryngol Otol 1997, 111:571-4. | Article I PubMed

14. Ansell SM, Habermann TM, Hoyer JD, Strickler JG, Chen MG and McDonald TJ: Primary laryngeal lymphoma. Laryngoscope 1997, 107:1502-6. | Article | PubMed

15. Marianowski R, Wassef M, Amanou L, Herman P and Tran-Ba-Huy P: Primary T-cell non-Hodgkin lymphoma of the larynx with subsequent cutaneous involvement. Arch Otolaryngol Head Neck Surg 1998, 124:1037-40. | Article | PubMed

16. Fung EK, Neuhauser TS and Thompson LD: Hodgkin-like transformation of a marginal zone B-cell lymphoma of the larynx. Ann Diagn Pathol 2002, 6:61-6. | Article | PubMed

17. Zhao JD, Cai XL and Wang TD: [The clinical features of laryngeal malignant lymphoma with 5 cases reported]. Lin Chuang Er Bi Yan Hou 
Bayoumi et al. Hematology and Leukemia 2013,

Ke Za Zhi 2000, 14:70-1. | PubMed

18. Hadjileontis CG, Kostopoulos IS, Kaloutsi VD, Nikolaou AC, Kotoula VA and Papadimitriou CS: An extremely rare case of synchronous occurrence in the larynx of intravascular lymphoma and in situ squamous cell carcinoma. Leuk Lymphoma 2003, 44:1053-7. | Article | PubMed

19. Palenzuela G, Bernard F, Gardiner Q and Mondain M: Malignant B cell non-Hodgkin's lymphoma of the larynx in children with Wiskott Aldrich syndrome. Int J Pediatr Otorhinolaryngol 2003, 67:989-93. | Article | PubMed

20. Kania RE, Hartl DM, Badoual C, Le Maignan C and Brasnu DF: Primary mucosa-associated lymphoid tissue (MALT) lymphoma of the larynx. Head Neck 2005, 27:258-62. | Article | PubMed

21. Roca B, Vidal-Tegedor B and Moya M: Primary non-hodgkin lymphoma of the larynx. South Med J 2005, 98:388-9. I Article I PubMed

22. Andratschke $\mathrm{M}$, Stelter $\mathrm{K}$, Ihrler $\mathrm{S}$ and Hagedorn $\mathrm{H}$ : Subglottic tracheal stenosis as primary manifestation of a marginal zone B-cell lymphoma of the larynx. In Vivo 2005, 19:547-50. | Article I PubMed

23. Word R, Urquhart AC and Ejercito VS: Primary laryngeal lymphoma: case report. Ear Nose Throat J 2006, 85:109-11. | Article | PubMed

24. Steffen A, Jafari C, Merz H, Galle J and Berger G: Subglottic MALT Iymphoma of the larynx--more attention to the glottis. In Vivo 2007, 21:695-8. | Article | PubMed

25. Tardio JC, Moreno A, Perez C, Hernandez-Rivas JA and Lopez-Carreira $\mathrm{M}$ : Primary laryngeal T/NK-cell lymphoma, nasal-type: an unusual location for an aggressive subtype of extranodal lymphoma. Eur Arch Otorhinolaryngol 2008, 265:705-8. | Article | PubMed

26. Monobe $H$, Nakashima $M$ and Tominaga $K$ : Primary laryngeal natural killer/T-cell lymphoma--report of a rare case. Head Neck 2008, 30:152730. | Article I PubMed

27. Elmazghi A, Elkacemi H, Lalya I, Zaidi H, Harmouch A, Kanouni L, Kebdani $\mathrm{T}$, Hassouni $\mathrm{K}$, Benjaafar $\mathrm{N}$ and Elgueddari B: [Primary malignant nonHodgkin lymphoma of the larynx: report of a case]. Pan Afr Med J 2011, 9:17. | Article | PubMed Abstract | PubMed Full Text

28. Uri N, Schindler Y, Quitt M, Valkovsky O and Barzilai G: Primary NK/T-cell lymphoma of the larynx. Ear Nose Throat J 2012, 91:206-7. I PubMed

29. Naciri S, Bennani-Baiti AA, Glaoui M, Mouzount H, Ghanem S, Essakali L, Kzadri $\mathrm{M}$ and Errihani $\mathrm{H}$ : Mantle cell lymphoma of the larynx: Primary case report. J Med Case Rep 2012, 6:201. | Article | PubMed Abstract | PubMed Full Text

30. Smith MS, Browne JD and Teot LA: A case of primary laryngeal T-cell lymphoma in a patient with acquired immunodeficiency syndrome. Am J Otolaryngol 1996, 17:332-4. | Article | PubMed

31. Simo R, Hartley C, Malik T, Wilson GE, Taylor PH and Mandal BK: Primary non-Hodgkin's lymphoma of the larynx in an AIDS patient. J Laryngol Otol 1998, 112:77-80. | Article | PubMed

32. de Bree R, Mahieu HF, Ossenkoppele GJ and van der Valk P: Malignant lymphoma of mucosa-associated lymphoid tissue in the larynx. Eur Arch Otorhinolaryngol 1998, 255:368-70. | Article | PubMed

33. Cheng CJ, Chen PR, Liu MC, Kuo MS and Hsu YH: Primary malignant lymphoma of mucosa-associated lymphoid tissue of larynx. Otolaryngol Head Neck Surg 1999, 121:661-2. I Article I PubMed

34. Ohta N, Suzuki H, Fukase S, Ksajima N and Aoyagi M: Primary nonHodgkin's lymphoma of the larynx (Stage IE) diagnosed by gene rearrangement. J Laryngol Otol 2001, 115:596-9. | Article I PubMed

35. Cavalot AL, Preti G, Vione N, Nazionale G, Palonta F and Fadda GL: Isolated primary non-Hodgkin's malignant lymphoma of the larynx. J Laryngol Otol 2001, 115:324-6. | Article | PubMed

36. Mok JS, Pak MW, Chan KF, Chow J and Hasselt CA: Unusual T- and T/ NK- cell non-Hodgkin's lymphoma of the larynx: a diagnostic challenge for clinicians and pathologists. Head Neck 2001, 23:625-8. | Article | PubMed

37. Nayak JV, Cook JR, Molina JT, Branch MP, Branstetter BFt, Ferris RL and Myers EN: Primary lymphoma of the larynx: new diagnostic and therapeutic approaches. ORL J Otorhinolaryngol Relat Spec 2003 65:321-6. | Article I PubMed
38. Caletti G, Togliani T, Fusaroli P, Sabattini E, Khodadadian E, Gamberi B, Gobbi $M$ and Pileri S: Consecutive regression of concurrent laryngeal and gastric MALT lymphoma after anti-Helicobacter pylori therapy. Gastroenterology 2003, 124:537-43. I Article I PubMed

39. King AD, Yuen EH, Lei KI, Ahuja AT and Van Hasselt A: Non-Hodgkin lymphoma of the larynx: CT and MR imaging findings. AJNR Am J Neuroradiol 2004, 25:12-5. | Article | PubMed

40. Agada FO, Mistry D, Grace AR and Coatesworth AP: Large B-cell nonHodgkin's lymphoma presenting as a laryngeal cyst. J Laryngol Otol 2005, 119:658-60. | Article | PubMed

41. Patiar S, Ramsden JD and Freeland AP: B-cell lymphoma of the larynx in a patient with rheumatoid arthritis. J Laryngol Otol 2005, 119:646-8. I Article I PubMed

42. Korst RJ: Primary lymphoma of the subglottic airway in a patient with Sjogren's syndrome mimicking high laryngotracheal stenosis. Ann Thorac Surg 2007, 84:1756-8. I Article | PubMed

43. Monobe $\mathrm{H}$, Nakashima $\mathrm{M}$ and Tominaga $\mathrm{K}$ : Primary laryngeal natural killer/T-cell lymphoma--report of a rare case. Head Neck 2008, 30:152730. | Article | PubMed

\section{Citation:}

Bayoumi Y, Maklad A M, Tunio M A, Fatani H, Mohamed R A, AlSaeed E F and Asiri M A: Clinicopathological features and treatment outcomes of primary laryngeal lymphomas in saudi population. Hematol Leuk 2013, 1:5.

http://dx.doi.org/10.7243/2052-434X-1-5 